\title{
OVERCOMING OBSTACLES TO IMPLEMENTING THE UN DECLARATION ON THE RIGHTS OF INDIGENOUS PEOPLES IN CANADA
}

\author{
Brenda L. Gunn*
}

The majority vote by the General Assembly, which brought the UN Declaration on the Rights of Indigenous Peoples into existence as an international instrument, was just the first step. Now the long and difficult road of implementation begins. Implementation requires the application of international law in a specific national context. This article explores the potential obstacles to implement the UN Declaration in Canada and suggest avenues to overcome these obstacles. This article concludes that the main obstacle is not a legal one, but rather a lack of political will. Given the limited understandings of the UN Declaration as an international instrument and how international law applies in Canada, this article provides an overview of the significance of a Declaration in international law and also explains how international law applies in Canada. The main recommendation to promote implementation is greater education on the UN Declaration. However, there are also many actions that Indigenous peoples, lawyers and advocates can take to promote implementation in legal and political domains that are discussed at the end of the article.

Le vote majoritaire de l'Assemblée générale, qui a donné naissance à la Déclaration des Nations unies sur les droits des peuples autochtones comme instrument international, était la toute première étape. Commence maintenant le long et difficile parcours vers sa mise en œuvre. Cette mise en œuvre requiert l'application du droit international dans un contexte national particulier. Le présent article examine les obstacles potentiels à la mise en ouvre de la Déclaration des Nations unies au Canada et propose des avenues pour surmonter ces obstacles. Cet article conclut que le principal obstacle n'est pas de nature juridique, mais réside dans l'absence de volonté politique. Étant donné que la Déclaration des Nations unies en tant qu'instrument international et la façon dont le droit international s'applique au Canada ne sont pas bien compris, cet article offre un aperçu de la signification d'une Déclaration en droit international et explique également comment le droit international s'applique au Canada. Pour promouvoir sa mise en œuvre, on recommande principalement une éducation accrue concernant la Déclaration des Nations unies. Il existe en outre bon nombre de mesures que les peuples autochtones, les avocats et les défenseurs de droits peuvent prendre pour encourager sa mise en ouvre dans les milieux juridiques et politiques. Ces mesures sont abordées à la fin de l'article.

Robson Hall Faculty of Law, University of Manitoba. I would like to thank the University Research Grants Program at the University of Manitoba for their financial support of this research. 


\section{INTRODUCTION}

Indigenous peoples fought for decades for international recognition of their inherent rights. Over a 30year period, Indigenous peoples and their advocates worked with member-states and the United Nations [UN] to draft and negotiate the United Nations Declaration on the Rights of Indigenous Peoples. ${ }^{1}$ The UN Declaration is significant because it is

the only declaration in the UN which was drafted with the rights-holders, themselves, the Indigenous Peoples. We see this is as a strong declaration which embodies the most important rights we and our ancestors have long fought for; our right of selfdetermination, our right to own and control our lands, territories and resources, our right to free, prior and informed consent, among others. Each and every article of this declaration is a response to the cries and complaints brought by indigenous peoples before the UN - Working Group on Indigenous Populations [WGIP]. This is a declaration which makes the opening phrase of the UN Charter, "We the Peoples..." meaningful for the more than 370 million indigenous persons all over the world. ${ }^{2}$

The UN Declaration, as a remedial instrument, is a major turning point for the promotion and protection of Indigenous peoples' rights, including their human rights. The majority vote by the General Assembly, which brought the UN Declaration into existence as an international instrument, is just the first step. Now the long and difficult road of implementation begins. In his 2006 report, the former Special Rapporteur acknowledged the existence of an implementation gap between law and practice. ${ }^{3}$ His research found that "not only are there contradictions in the laws themselves, which make their application enormously complex and difficult, but we can also detect an increasing gap between legal framework and public policy." 4 Thus while the UN Declaration contains strong language articulating the rights and promoting implementation, the UN Declaration will not have any effect unless actions are taken to fully implement it at national legal and policy levels.

While Indigenous peoples around the world have similar experiences of colonization, dispossession and attempts at assimilation, there are many differences amongst Indigenous peoples that heightened tensions amongst Indigenous delegates at times during negotiations. Accommodating these differences required drafting minimum standards and a generally acceptable framework, which could be contextually implemented addressing the particular context of the Indigenous peoples' and the nationstate within which they reside. While Canada expressed concerns about the level of generality contained

1 GA Res 61/295 (Annex), UN GAOR, 61st Sess, Supp No 49, Vol III, UN Doc A/61/49 (2008) 15. [UN Declaration]

2 Victoria Tauli-Corpuz, "Statement of Victoria Tauli-Corpuz, Chair of the UN Permanent Forum on Indigenous Issues on the Occasion of the Adoption of the UN Declaration on the Rights of Indigenous Peoples” at the $61^{\text {st }}$ Session of the UN General Assembly, 13 September 2007, New York.

3 Rodolfo Stavenhagen, Commission on Human Rights, Report of the Special Rapporteur on the situation of human rights and fundamental freedoms of indigenous people, UNOHCHR, UN Doc E/CN.4/2006/78, 16 February 2006 [Special Rapporteur].

4 Rodolfo Stavenhagen, “Making the Declaration Work” in Claire Charters \& Rodolfo Stavenhagen, eds, Making the Declaration Work: The United Nations Declaration on the Rights of Indigenous Peoples (Copenhagen: International Work Group for Indigenous Affairs, 2009) 352 [Making the Declaration Work] at 353. 
within the UN Declaration when they voted against the UN Declaration, this flexibility strengthens the UN Declaration because it provides for a greater contextual application of the rights in particular national contexts. ${ }^{5}$

The UN Declaration is not perfect. During the negotiation process, certain compromises were made, but the final text of the UN Declaration largely achieves the goals of Indigenous peoples. ${ }^{6}$ While some academics remain critical of the potential of the UN Declaration, many Indigenous peoples are of the view that the $U N$ Declaration represents a positive development for the realization of Indigenous peoples' rights. ${ }^{7}$ The UN Declaration

challenges or at least pushes the liberal human rights paradigm by explicitly referring to the right to self-determination, embracing collective rights and expressing an understanding of the interrelationship between right to heritage, land and development. On the other hand, it represents the continued power and persistence of an international human rights paradigm that eschews strong forms of indigenous self-determination and privileges individual civil and political rights. ${ }^{8}$

Indigenous peoples from across Canada actively participated in the development of the UN Declaration, from the original Working Group on Indigenous Populations draft text through to the final draft submitted to the General Assembly. ${ }^{9}$ Throughout this negotiation process, Canada's position on the $U N$ Declaration changed and ultimately ended with Canada voting against the UN Declaration in the General Assembly. ${ }^{10}$ Three years after its adoption by the General Assembly, Canada gave a qualified endorsement of the UN Declaration. ${ }^{11}$ Regardless of Canada's position, the UN Declaration is an international norm ${ }^{12}$ that has legal and moral relevance in Canada.

Implementation requires the application of international law in a specific national context. The former Special Rapporteur speaks of this as the process of "glocalization" or "thinking globally (the

5 Stephen Allen, "The UN Declaration on the Rights of Indigenous Peoples and the Limits of the International Legal Project" in Stephen Allen \& Alexandra Xanthaki, eds, Reflections on the UN Declaration on the Rights of Indigenous Peoples (Portland: Hart Publishing, 2011) 225 at 234-5.

6 Alexandra Xanthaki, “Indigenous Rights in International Law Over the Last 10 Years and Future Developments” (2009) 10:1 Melbourne Journal of International Law 27 at 29.

7 Will Kymlicka, “Beyond the Indigenous/Minority Dichotomy,” in Allen \& Xanthaki, supra note 5, 183 at 205. Kymlicka states that the UN Declaration rests on "shifting sands" because of the potential legal firewall it creates for the realization of minority rights. Instead of seeing it as a positive development, Kymlicka argues that indigenous rights cannot be realized as long as they create a "firewall" for minority rights.

8 Karen Engle, "On Fragile Architecture: The UN Declaration on the Rights of Indigenous Peoples in the Context of Human Rights” (2011) 22:1 EJIL 141 at 142.

9 Indigenous participation has varied over the years, but includes the Assembly of First Nations, the Native Women's Association of Canada, the Métis National Council, the Grand Council of the Crees, other regional political organizations and also various Aboriginal communities. A detailed list of participation is annexed to the report submitted after each session of the various Working Groups and Councils, which are available through the UN web site. GAOR, $61^{\text {st }}$ session, $107^{\text {th }}$ plenary meeting, 13 September 2007, UN Doc A/61/PV.107.

11 Aboriginal Affairs and Northern Development Canada, News Release, “Canada’s Statement of Support on the United Nations Declaration on the Rights of Indigenous Peoples” (12 November, 2010), online: Aboriginal Affairs and Northern Development Canada <http://www.ainc-inac.gc.ca/ap/ia/dcl/stmt-eng.asp> [“Canada’s Endorsement”].

12 Sharon Venne, “The Road to the United Nations and Rights of Indigenous Peoples” (2011) 20:3 Griffith LR 557 at 575. 
Declaration) and acting locally (the implementation process)." ${ }^{13}$ As the UN Declaration was negotiated in the international arena outside domestic democratic processes, translating its general provisions into a specific domestic context is important to subject the $U N$ Declaration to the uncertainties of political negotiation at the national level. ${ }^{14}$

While much has been written on the $U N$ Declaration and its significance as an international instrument, little academic attention has been paid to actualizing the UN Declaration in Canada, particularly given the Canadian domestic context of existing constitutional recognition of Aboriginal and treaty rights in s. 35(1) of the Constitution Act, $1982 .{ }^{15}$ In this article, I explore the potential obstacles to implementing the UN Declaration in Canada and suggest avenues to overcome these obstacles. The identification of potential barriers has been ascertained through academic legal research, participation in key United Nations conferences (including the UN Permanent Forum on Indigenous Issues as well as the Expert Mechanism on the Rights of Indigenous Peoples), conducting community legal education seminars on the UN Declaration, as well as consideration of State responses to the Expert Mechanism on the Rights of Indigenous Peoples questionnaire on best practices regarding implementation strategies for the UN Declaration. As the existing literature is more focused on the theoretical implications of the UN Declaration, this article offers a bridge across the divide between the current theoretical literature and its practical application. This article in part addresses calls made by educators, practitioners and advocates for information to incorporate the UN Declaration into their work.

The article begins by providing a brief overview of the UN Declaration, including the process of drafting and negotiating the text before identifying potential obstacles to implementing the $U N$ Declaration in Canada. This history is an important background to understanding the identified obstacles and the implementation strategies. This article concludes that the main obstacle to implementing the UN Declaration in Canada is not a legal one, but rather a lack of political will. ${ }^{16}$ Apathy toward the UN Declaration is connected to limited understandings of the UN Declaration as an international instrument and how international law applies in Canada. Given the qualms regarding the $U N$ Declaration, the article identifies education on the $U N$ Declaration as an important first step to garnering the necessary political will for implementation to occur. During this process of consciousness-raising, there are many actions that Indigenous peoples, lawyers and advocates can take to promote implementation in legal and political domains, which are outlined in this article. As such, the brief primer on the $U N$ Declaration as an international instrument provides this critical component of education.

\section{BACKGROUND ON THE UN DECLARATION}

To contextualize the discussion on overcoming obstacles to implement the UN Declaration in Canada, this section provides a brief history of and introduction to the UN Declaration. It begins with a description of the General Assembly vote, particularly highlighting Canada's negative vote. The section

13 Stavenhagen, Making the Declaration Work, supra note 4 at 358.

14 Allen, supra note 5 at 234-5.

15 Constitution Act, 1982, being Schedule B to the Canada Act 1982 (UK), 1982, c 11, part II.

16 It should be noted that some States and academics argue that as a declaration there is no obligation to implement. For example see, the explanation of votes at the General Assembly, supra note 10. See also, Allen supra note 5 at 225. 
then describes the significance of the UN Declaration to Indigenous peoples, but also to the United Nations human rights system. Finally, a brief overview of the UN Declaration's basic contents is provided, including provisions which mandate actions to implement the Declaration it.

On September 13, 2007 the UN Declaration became part of international law when an overwhelming majority of States in the United Nations General Assembly voted in its favour. ${ }^{17}$ The vote recorded $143^{18}$ States in favour of the UN Declaration and four states against (Australia, Canada, New Zealand and the United States). As well as negative votes, there were eleven abstentions and thirty-four absences. ${ }^{19}$ The majority of the abstaining votes and absences came from African countries. ${ }^{20}$ While some academics argue that the abstentions and absences were a result of African countries trying to reconcile their post-colonial identities, ${ }^{21}$ others argue some Africa States wanted to remain neutral given the strong opposition from certain States. ${ }^{22}$

In the General Assembly, Canada explained its negative vote:

Canada has significant concerns with respect to the wording of the current text, including the provisions on lands, territories and resources; on free, prior and informed consent when used as a veto; on self government without recognition of the importance of negotiations; on intellectual property; on military issues; and on the need to achieve an appropriate balance between the rights and obligations of indigenous peoples, Member States and third parties. ${ }^{23}$

Australia, New Zealand and the United States also explained their negative vote by citing concerns with the specific wording of different provisions and some concerns with the process taken to finalize the text; these States would have preferred to undertake further negotiations before the final text was submitted to the General Assembly. ${ }^{24}$

Australia, Canada, New Zealand and the United States also posited that the UN Declaration should have been debated until full international consensus was reached. ${ }^{25}$ This proposal set the bar for

17 GA Res 61/295 (Annex), UNGAOR, 61st Sess, Supp No 49, Vol III, UN Doc A/61/49 (2008) 15.

18 The General Assembly Official Records indicate that 143 States voted in favour of the Declaration and that

"Subsequently the delegation of Montenegro advised the Secretariat that it had intended to vote in favour" of the

Declaration. Hence some authors put the count of votes for the Declaration at 144. GA Res 61/295 (Annex), UNGAOR, 61st Sess, Supp No 49, Vol III, UN Doc A/61/49 (2008) 15 at 19.

19 Alberta Barume notes that "a staggering 15 African countries were absent from the room (Chad, Côte d'Ivoire, Equatorial Guinea, Eritrea, Ethiopia, Gambia, Guinea-Bissau, Mauritania, Morocco, Rwanda, Sao Tome and Principe, Seychelles, Somalia, Togo and Uganda)" on the day of the General Assembly vote on the Declaration, "most of whom had been present and voted in favor of the Namibian-led deferment Resolution almost a year earlier." Albert Barume, "Responding to Concerns of the African States" in Charters \& Stavenhagen, supra note 4, 170 at 180-1.

20 Barume, ibid. See also Dwight G Newman, "The Law and Politics of Indigenous Rights in the Postcolonial African State” (2008) 102 Proceedings of the Annual Meeting (Am Soc of Int’l L) 69 at 69.

21 Barume, supra note 19.

22 Ibid.

23 Supra note 10.

24 Ibid.

25 Ibid. 
adopting the $U N$ Declaration higher than for any other international human rights instrument. ${ }^{26}$ Requiring negotiations until all States were ready to vote in favour would have effectively given certain States a veto on the $U N$ Declaration, preventing adoption until their specific concerns were met. Fortunately, the push for additional debate was denied. Within four years of the General Assembly vote, all States that had originally voted against UN Declaration and several abstainers had changed their position and now endorse the

UN Declaration. ${ }^{27}$ Today, the UN Declaration enjoys almost unanimous support from the international community. ${ }^{28}$

Many authors have written on the significance of the UN Declaration for both Indigenous peoples and international law. ${ }^{29}$ Some have referred to the UN Declaration as "a major victory for Indigenous Peoples who actively took part in crafting this Declaration." ${ }^{30}$ Others have explained that through the UN Declaration, the United Nations, nation-states and Indigenous peoples "reconciled with past painful histories and decided to march into the future on the path of human rights." ${ }^{31}$ While some scholars express doubt as to the significance the $U N$ Declaration, ${ }^{32}$ most Indigenous advocates would agree that the UN Declaration provides “a framework for States to link and integrate with Indigenous peoples, to

26 Depending on your definition of consensus, even the Universal Declaration of Human Rights was not passed by a full consensus, as there were eight abstentions.

27 The Labour government in Australia endorsed the Declaration in 2009. Australia (Jenny Macklin, Minister for Families, Housing, Community Services and Indigenous Affairs), "Statement on the United Nations Declaration on the Rights of Indigenous Peoples”, Parliament House, Canberra (April 3, 2009), online: Government of Australia <http://www.jennymacklin.fahcsia.gov.au/internet/jennymacklin.nsf/content/un_declaration_03apr09.htm>. New Zealand too has since indicated their support for the Declaration. Dr. Pita Sharples, "New Zealand Statement at the Opening Ceremony to the Ninth Session of the Permanent Forum on Indigenous Issues” April 19, 2010. online: doCip Online Documentation $<$ http://docip.org/gs-dl/cgi-bin/library?a=q\&c=cendocdo\&q=Pita\%20SHARPLES >. Most recently, the United States has indicated its endorsement for the Declaration on December 15, 2010. United States State Department, “Announcement of U.S. Support for the United Nations Declaration on the Rights of Indigenous Peoples” December 15, 2010 online: U.S. Department of State <http://www.sta-te.gov/documents/organization/153223.pdf>. Additionally, several States that abstained from voting have since indicated their support for the Declaration. Colombia is one example: Colombia, "Gobierno anuncia respaldo unilateral a la Declaracion de Naciones Unidas sobre los Derechos de los Pueblos Ind'1genas" (21 April 2009), online: <http://web.presidencia.gov.co/s-p/2009/abril/21/10212009.html>.

28 Siegfried Wiessner claims we have now "arrived at a global consensus on UNDRIP". "Re-Enchanting the World: Indigenous Peoples’ Rights as Essential Parts of a Holistic Human Rights Regime,’ (2010) 15(1) UCLA Journal Int’l L and Foreign Aff 239 at 253 claims we have now “arrived at a global consensus on UNDRIP.”

29 See for e.g., Megan Davis, “To Bind or Not to Bind: The United Nations Declaration on the Rights of Indigenous Peoples Five Years On” (2013) 19 Australia International Law Journal 17; Megan Davis, “United Nations Declaration on the Rights of Indigenous Peoples” (2008) 9 Melbourne Journal of International Law 439; Jeremie Gilbert, "Indigenous Rights in the Making: The United Nations Declaration on the Rights of Indigenous Peoples” (2007) 14 International Journal on Minority and Group Rights 207 at 229-30; Mauro Barelli, “The Role of Soft Law in the International Legal System: The Case of the United Nations Declaration on the Rights of Indigenous Peoples” (2009) 58 ICLQ 957, 968; Clive Baldwin \& Cynthia Morel, "Using the United Nations Declaration on the Rights of Indigenous Peoples in Litigation" in Allen \& Xanthaki, supra note 5, 122; and Emmanuel Voyiakis, "Voting in the General Assembly as Evidence of Customary International Law?” in Allen \& Xanthaki, supra note 5, 207.

30 Tauli-Corpuz, supra note 2.

31 Ibid.

32 For e.g., see Karen Engle, supra note 8. See also Kymlicka, supra note 7 at 183. 
initiate new and positive relations but this time without exclusion, without discrimination and without exploitation."33

The UN Declaration is a very long and detailed instrument, containing twenty-four preambular paragraphs and forty-six operative articles. The Preamble sets its context by recognizing the injustices of colonization and contextualizes the rights within the broader international human rights system. The preamble also recognizes that the realization of Indigenous peoples' rights "will enhance harmonious and cooperative relations between the State and indigenous peoples, based on principles of justice, democracy, respect for human rights, non-discrimination and good faith." ${ }^{34}$ Momentously, the UN Declaration recognizes that the rights of Indigenous peoples are collective rights of communities and nations, not solely rights held by individual Indigenous people. ${ }^{35}$ The UN Declaration does not provide a definition of who is Indigenous for the purposes of asserting the rights, but allows for this determination to be made on a case-by-case basis.

The scope of the UN Declaration is broad and covers almost all aspects of Indigenous peoples' lives. It begins by unequivocally stating that Indigenous peoples have the right to equality and nondiscrimination - a right to all human rights and fundamental freedoms recognized under international law. ${ }^{36}$ Article 3 recognizes Indigenous peoples' right to self-determination, which includes the right to autonomy or the right to self-government over internal affairs. ${ }^{37}$ As self-determination is a foundational right from which all other rights flow, the bulk of the remaining articles recognize the right to life, integrity and security; right to culture, religious and linguistic identity; right to education, public information and employment; right to participation in decision making and free, prior and informed consent; economic and social rights such as the right to adequate standards of living and economic wellbeing; right to lands, territories and resources, right to have treaties, agreements and other constructive arrangements upheld; and Indigenous women's rights. ${ }^{38}$

The final provisions discuss implementation. ${ }^{39}$ Implementing the UN Declaration will be key for the full and effective realization of Indigenous peoples' rights. As Victoria Tauli-Corpuz, former chair of the UN Permanent Forum on Indigenous Issues, stated on the day of the vote in the General Assembly, "effective implementation of the Declaration will be the test of commitment of States and the whole international community to protect, respect and fulfill indigenous peoples' collective and individual rights." 40 However, the unfortunate reality is that there already exists an implementation gap between

\footnotetext{
33 Les Malezer, Chairman Global Indigenous Caucus, "Statement made on the Adoption of the UN Declaration on the Rights of Indigenous Peoples, September 13, 2007 online: International Work Group for Indigenous Affairs <http://www.iwgia.org/sw248.asp>.

34 UN Declaration, supra note 1 at preambular para 17.

35 "Indigenous peoples have the right to full enjoyment, as a collective or as individuals, of all human rights and fundamental freedoms as recognized I the Charter of the United Nations, the Universal Declaration of Human Rights and international human rights law.” Ibid at Article 1.

36 Ibid at Articles 1 and 2.

$37 \quad$ Ibid at Articles 3 and 4.

38 Ibid at articles 5-37.

39 Ibid at articles 38-46.

40 Tauli-Corpuz, supra note 2.
} 
the laws and their application on the ground. ${ }^{41}$ Stephen Allen describes how the implementation gap can manifest:

\begin{abstract}
the failure to enact secondary legislation to give effect to pertinent constitutional provisions or broad principles enunciated in primary legislation; bureaucratic inertia or ignorance; willful disregard or corruption on the part of public officials; uncoordinated and conflicting government policies; inadequate monitoring procedures; and insufficient indigenous consultation/participation in public decision-making processes. ${ }^{42}$
\end{abstract}

Some States, including Canada, argue that the $U N$ Declaration is merely aspirational and therefore they do not need to take action to implement it. ${ }^{43}$ However, throughout the UN Declaration, strong language is used obliging the State to take steps to ensure these rights are upheld. For example, the preamble and articles 38, 39, and 40 of the UN Declaration require States to cooperate with Indigenous peoples in taking measures to implement and interpret the provisions of the UN Declaration, including providing access to assistance for the fulfillment of the rights guaranteed therein. The Expert Mechanism on the Rights of Indigenous Peoples report also identified best practices to include, "partnerships between states and indigenous peoples, which facilitated the participation of indigenous peoples in decision making." 44 As such, there is a strong need for States and Indigenous peoples to work together to implement the UN Declaration to avoid widening the implementation gap.

The UN Declaration also obligates the United Nations and its bodies, specialized agencies, and States to promote respect for and application of the UN Declaration. ${ }^{45}$ Articles 41 and 42 require that agencies of the United Nations and intergovernmental organizations contribute to, and assist in, the process of implementation for the full realization of its provisions. However, implementation of the UN Declaration is not limited to States or international bodies. Indigenous peoples can also take steps to implement the UN Declaration within their own nations and communities. Kenneth Deer advocates that "you do not ask for rights; you assert them. When rights are asserted, they grow... Indigenous peoples must assert and exercise our inherent rights. Exercising our rights is what makes us who we are."46

This brief background set out the significance and the scope of the UN Declaration, including provisions mandating implementation. This background also provided a general overview of the substantive rights recognized in the UN Declaration that must be implemented. Importantly, this section demonstrated the growing consensus on the UN Declaration and for the reconciliation framework it provides. The next section identifies some key barriers to implementation in Canada before presenting avenues to overcome these obstacles to achieve the full realization of the rights contained in the $U N$ Declaration.

41 Stavenhagen, Special Rapporteur, supra note 3 at para 5.

42 Allen, supra note 5 at 253.

43 “Canada’s Endorsement”, supra note 11.

44 Wilton Littlechild, UN Human Rights Council, "Report of the Expert Mechanism on the Rights of Indigenous Peoples on its fifth session”, 17 August 2012, UN Doc A/HR/C/21/52.

45 UN Declaration, supra note 1 at Articles 41 and 42.

46 Kenneth Deer, "Reflections on the Development, Adoption, and Implementation of the UN Declaration on the Rights of Indigenous Peoples” in Jackie Hartley, Paul Joffe \& Jennifer Preston, eds, Realizing the UN Declaration on the Rights of Indigenous Peoples: Triumph, Hope and Action, (Saskatoon: Purich Publishing Ltd, 2010) 18 at 28. 


\section{OBSTACLES TO IMPLEMENTING THE UN DECLARATION IN CANADA}

Before a discussion on implementing the $U N$ Declaration in Canada can occur, it is important to understand the potential barriers that exist. The potential barriers include a lack of understanding of the UN Declaration's status an international instrument, a failure to appreciate international law and its application in Canada, a lack of political will, a narrow conception of equality coupled with a concern for recognizing special rights, and financial constraints. Identification of potential barriers allows a targeted implementation plan to be developed for the full and effective enjoyment of rights contained within the UN Declaration.

One of the main obstacles is the disagreement or lack of understanding on the legal status of the $U N$ Declaration. The Canadian government refers to it as an aspirational instrument that does not change Canadian law. ${ }^{47}$ Canada has also attempted to diminish the significance of the UN Declaration by qualifying its endorsement: "We are now confident that Canada can interpret the principles expressed in the Declaration in a manner that is consistent with our Constitution and legal framework." 48 This statement attempts to subordinate the UN Declaration to Canadian law and not allow the $U N$ Declaration to inform interpretations of Canadian law. A few academic commentators have also taken a narrow view of significance of the UN Declaration: "the Declaration's significance stems from the political legitimacy it embodies rather than its claimed international legal character." 49 Such positions are then used to justify non-action. As this understanding of the UN Declaration presents a major obstacle, the status of the UN Declaration in international law and within Canadian law will be discussed in greater detail below.

Many people (including Indigenous peoples in Canada) have accepted Canada's position that the $U N$ Declaration has no relevance or effect in Canada. Not only are people accepting Canada's position, but "too often, indigenous leaders are consumed with the day-to-day and more urgent issues facing their communities and have little time to consider activities taking place far away in Geneva." ${ }^{50}$ Manitoba Chiefs have voiced similar concerns. ${ }^{51}$ The Chiefs questioned how the UN Declaration could solve the day-to-day problems facing their communities such as lack of clean drinking water, housing shortages, unemployment, and youth suicide. ${ }^{52}$ The many pressures facing Indigenous peoples and a skepticism of its potential to effect change presents a potential barrier to implementing the UN Declaration.

The acceptance of Canada's position on the legal effect of the UN Declaration connects to another obstacle identified in the Expert Mechanism on the Rights of Indigenous Peoples' Report on Best Practices to Implement the UN Declaration: "one of the biggest challenges identified is the lack of awareness and knowledge of the Declaration and other international instruments on the rights of

\footnotetext{
47 “Canada’s Endorsement”, supra note 11.

48 Ibid.

49 Allen, supra note 5 at 225.

50 Dalee Sambo-Dorough, “The Significance of the Declaration on the Rights of Indigenous People's and Its Future Implementation” in Charters \& Stavenhagen, supra note 4, 264 at 273.

51 Brenda L Gunn on behalf of the Indigenous Bar Association, "Understanding and Implementing the UN Declaration" (Workshop presented to the Assembly of Manitoba Chiefs, October 17, 2011), [unpublished].

52 Ibid.
} 
indigenous peoples to ensure the respect for these rights." 53 In Canada, there is a general ignorance of international law and its application in Canada, including amongst the judiciary and legal profession. Looking at the court's comments in Mississaugas of Scugog Island exemplifies the lack of understanding of the role of international law in Canada. ${ }^{54}$ Sharpe J.A. refused to consider what was then the Draft Declaration on the Rights of Indigenous Peoples, holding

This convention, which Canada voted against and has not ratified, recognizes the right of indigenous peoples to 'self-determination,' to govern their own lands and to have their own distinct political, legal, economic, social and cultural institutions. While international law often is of assistance in the interpretation of domestic legal and constitutional norms, the general language of the Draft Declaration does not, in my view, provide any meaningful assistance to the resolution of the specific issue of Canadian constitutional law presented here. ${ }^{55}$

There are several errors in this passage including conflation of a Declaration and a convention, the belief that ratification is required for a Declaration to have legal effect, and that the UN Declaration contains language too broad to assist in the interpretation of Canadian constitutional law.

Most common law school programs offer a course on international law and perhaps international human rights law, but no law school mandates this education. Nor is international law or international human rights law included in the Federation of Law Societies of Canada national standard for academic requirements of a Canadian law degree. ${ }^{56}$ The recent Federation Task Force report proposed national requirements for common law degrees including basic skills, awareness of appropriate ethical values and core legal knowledge that law students can reasonably be expected to have acquired during the academic component of their education. ${ }^{57}$ As Canadian law schools review their curriculum to ensure they meet the minimum requirements set out by the Federation of Law Societies, understanding the application of international law in Canada is still not considered a core competency.

As will be demonstrated in greater detail below, there is no legal impediment to implementing the $U N$ Declaration in Canada; the issue is political will. Canadian lawyer and scholar Paul Joffe argues, “Canadian government's opposition to the Declaration is based upon ideological bias rather than on a

53 Expert Mechanism on the Rights of Indigenous Peoples, Human Rights Council, “Final summary of responses to the questionnaire seeking the views of States and indigenous peoples on best practices regarding possible appropriate measures and implementation strategies to attain the goals of the United Nations Declaration on the Rights of Indigenous Peoples,” Report of, 25 April 2013 UN Doc A/HRC/EMRIP/2013/3 at para 77.

54 Mississaugas of Scugog Island, 2007 ONCA 814, 287 DLR (4th) 452; leave to appeal to SCC refused, 32452 (April 24 , 2008).

55 Ibid at paras 46-7.

56 Federation of Law Societies of Canada, Task Force on the Canadian Common Law Degree, "Final Report” (October 2009), online: FLSC < http://www.flsc.ca/_documents/Common-Law-Degree-Report-C.pdf > at 5.

57 The Task Force's recommendations, which were adopted by the Federation of Law Societies, "reflect its view that every Canadian law school graduate entering a bar admission program or a recipient of an NCA Certificate of Qualification should understand, the foundations of law, including principles of common law and equity, the process of statutory construction and analysis and the administration of the law in Canada; the constitutional law of Canada that frames the legal system; and the principles of criminal, contract, tort, property and Canadian administrative law and legal and fiduciary principles in commercial relationships.” Ibid at 5. 
legitimate, legal rationale." ${ }^{58}$ Canada is becoming increasingly hostile towards international law, as indicated by Canada's statement of support for the UN Declaration where Canada stated its unwillingness to amend laws to conform to international standards. ${ }^{59}$ The lack of political will to take necessary measures to implement the $U N$ Declaration is a significant challenge to overcome.

Another struggle with implementing the $U N$ Declaration is State concerns with the principle of equality. The Expert Mechanism questionnaire noted

some States appear to perceive there to be a struggle to balance the recognition and implementation of the rights of indigenous peoples as articulated in the Declaration and the principle of equality. Equality continues to be interpreted by some States to prohibit specialized programmes aimed at achieving the goals of the Declaration. ${ }^{60}$

Stephen Allen also articulates concerns about the rights recognized within the UN Declaration and issues of equality: "while they might be grounded in the rhetoric of equality, they are privileged rights when compared with the entitlements held and exercised by other sub-State societal groups."61 Formalistic interpretations of equality and concerns regarding special or differential treatment may prevent state action to implement the rights within the UN Declaration.

Karen Engle discusses the tension between individual and collective rights expressed by several states as a potential obstacle to implementing the UN Declaration. ${ }^{62}$ This tension is connected to certain understandings of equality as highlighted by the statement of the New Zealand ambassador: "human rights are universal and apply in equal measure to all individuals. This means that one group cannot have human rights that are denied to other groups within the same nation-state."63 Given Canada's alliance with these States, Canada may have similar concerns about recognizing collective rights of a certain sub-group in Canada.

58 Paul Joffe, “Canada’s Opposition to the UN Declaration: Legitimate Concerns or Ideological Bias” in Hartley, Joffe \& Preston, supra note 46 at 182-183.

59 Beyond the statement of endorsement, there are other examples including Canada's response to Kyoto and the Durban negotiations. See "In Durban, Kyoto seems set to meet its end”, The Globe and Mail (7 December 2011) online: The Globe and Mail <http://www.theglobeandmail.com/news/world/in-durban-kyoto-seems-set-to-meet-itsend/article4180475/>. Furthermore, Canada had a very strong response to the UN Special Rapporteur on the Right to Food's report on Canada. See "Country Response to the Report of the Special Rapporteur on the Right to Food, Statement by the Delegation of Canada”, Human Rights Council 22 Session, Geneva, (4 March 2013), online: Canada Without Poverty < http://www.c-wp-csp.ca/wp-content/uploads/2013/03/Canadian-govt-response-to-DeSchutter_presented-Mar-4-2013.pdf $>$.

60 Expert Mechanism on the Rights of Indigenous Peoples, supra note 53at para 152.

61 Allen, supra note 5 at 243. See also concerns raised by Kymlicka, supra note 7 at 183.

62 Engle, supra note 8 at 149-150.

63 Statement by HE Ms Rosemary Banks, Ambassador and Permanent Representative of New Zealand, on behalf of Australia, New Zealand, and the United States, to United Nations Third Committee, 16 October 2006. Online: Ministry of Foreign Affairs and Trade <http://www.m-fat.govt.nz/Foreign-Relations/1-Global-Issues/Human-Rights/IndigenousPeoples/draftdec-jun07.php>. 
Notions of formal equality abound in Canadian legal ${ }^{64}$ and political history. In 1969, Prime Minister Trudeau and Minister Chretien developed the White Paper to eradicate the "special" Treaty/status Indians. ${ }^{65}$ This policy never materialized due to strong backlash. ${ }^{66}$ Supreme Court of Canada decisions articulating the scope of Aboriginal and treaty rights under s. 35(1) of the Constitution Act, 1982 have similar undercurrents of an aversion to perceived special rights. Chief Justice Lamer refers to s. 35(1) as "granting special constitutional protection to one part of Canadian society" 67 and not as a recognition of Indigenous peoples' inherent and pre-existing rights. Notions of formal equality were then used to limit the scope of s. 35(1) rights: "the court cannot look at those aspects of the aboriginal society that are true of every human society (e.g., eating to survive), nor can it look at those aspects of the aboriginal society that are only incidental or occasional to that society; the court must look instead to the defining and central attributes of the aboriginal society in question."68 Underlying this limited scope is the belief that the "special" rights of Indigenous peoples must only protect activities that are "special" or distinct to Indigenous peoples. Ongoing concerns about Indigenous peoples receiving "special” treatment present an obstacle to implementing the UN Declaration. It should be noted that the Expert Mechanism addressed equality concerns indicating a need to promote substantive equality which may require action to address their unique circumstances. ${ }^{69}$

A final challenge that exists is the financial implications of fulfilling the rights set out in the $U N$ Declaration because many States have limited resources to undertake the work to promote the rights of Indigenous peoples. ${ }^{70}$ Identifying funds and prioritizing Indigenous peoples' rights as recognized in the UN Declaration presents a real and political challenge for States. Exacerbating the financial challenges is the "clear tension between the rights established through international negotiation and supposed exigencies of national development found on indigenous peoples' lands." ${ }^{71}$ Where States rely on natural resource development activities as a source of revenue, these activities may run counter to the rights set out in the UN Declaration. Thus leaving open the argument that implementing the UN Declaration may potentially decrease available funds to support specialized programs.

These barriers may seem like significant, almost impossible obstacles to overcome. While not underestimating the difficulties these challenges pose, one must not let obstacles justify inaction. The remainder of this paper presents practical solutions to overcoming these obstacles to fully realize the rights recognized in the UN Declaration and achieve the goal of "harmonious and cooperative relations

64 See e.g. early equality decisions by the Supreme Court of Canada on equality provisions under the Canadian Bill of Rights such as $R$ v Drybones, [1970] SCR 282; and Attorney General of Canada v Lavell, [1974] SCR 1349. Canada, Statement of the Government of Canada on Indian Policy, 1969, online: Aboriginal Affairs and Northern Development <http://www.aadnc-aandc.gc.ca/dam/dam-inter-hq/staging/texte-text/cp1969_1100100010190_eng.pdf>.

66 This would include what has been called the "Red Paper." Indian Chiefs of Alberta, Citizens Plus (presentation by Indian Chiefs of Alberta to Right Honorable PE Trudeau, Prime Minister of and the Government of Canada), June 1970. Reprinted with permission in (2011) 1.1 Aboriginal Policy Studies 188. $R v$ Van der Peet, [1996] 2 SCR 507 at para 20.

$68 \quad$ Ibid at para 56.

69 Expert Mechanism on the Rights of Indigenous Peoples, supra note 53at para 152.

$70 \quad$ Ibid at para 80.

71 Julian Burger, “The UN Declaration on the Rights of Indigenous Peoples: From Advocacy to Implementation” in Allen \& Xanthaki, supra note 5, 41 at 41. 
between the State and indigenous peoples, based on principles of justice, democracy, respect for human rights, non-discrimination and good faith." ${ }^{72}$

\section{OVERCOMING OBSTACLES TO FULLY IMPLEMENT THE UN DECLARATION}

This section identifies strategies to implement the UN Declaration in Canada. Implementation of the UN Declaration is critical to shift the $U N$ Declaration from an international instrument to actual domestic laws, policies and administrative measures. ${ }^{73}$ In particular, implementing the UN Declaration is important because it presents a road map of action to realize Indigenous peoples' rights, ${ }^{74}$ which is critical for reconciliation in Canada pursued in a spirit of partnership and mutual respect. ${ }^{75}$ The process and outcome of implementation can have significant impact on the situation of Indigenous peoples in Canada.

\section{A. Status of the $U N$ Declaration as an International Instrument}

As one of the main barriers to implementing the $U N$ Declaration in Canada is the lack of understanding of its status as an international instrument, this section explains the legal significance of a declaration. This explanation is done with a particular eye to addressing Canada's statements on its "aspirational" character. ${ }^{76}$ This section argues that the UN Declaration does have legal effect in addition to political and moral significance. ${ }^{77}$

While Canada refers to the UN Declaration as an "aspirational" document that is not legally binding and not reflective of customary international law, ${ }^{78}$ international scholars and legal experts have contested these assertions. ${ }^{79}$ Canada's contention that the UN Declaration is aspirational is disingenuous because "states never perceived the provisions of the Declaration as mere aspirations or they would not have been so active in its elaboration." ${ }^{\prime 80}$ As there is debate in the academic arena on the significance of the UN Declaration, it is necessary to engage in a fuller analysis of the significance of declarations.

As declarations arise through several different methods, the significance of a particular declaration requires understanding the broader context in which it was created. As a resolution of the General Assembly, the UN Declaration is a recommendation by the General Assembly. ${ }^{82}$ General Assembly resolutions can inspire the development of or sharpen existing customary practices. ${ }^{82}$

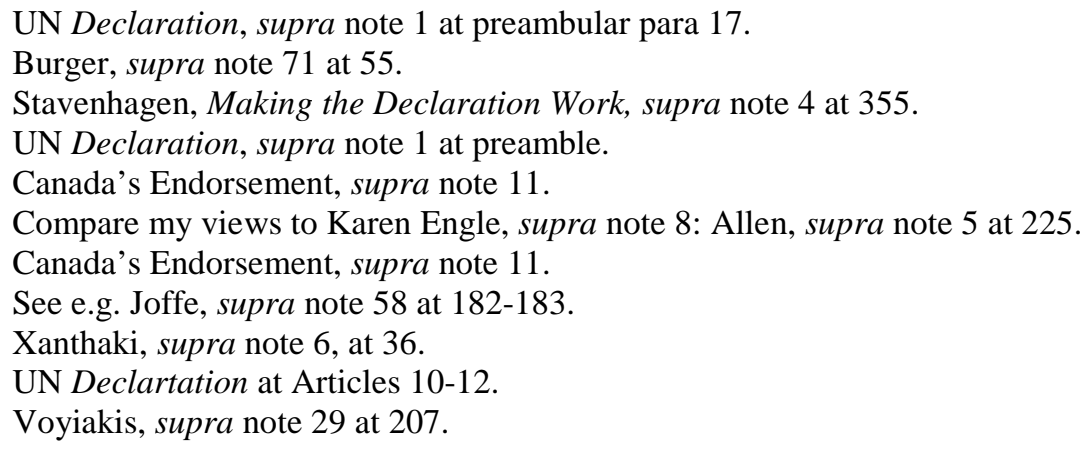


It is true that a declaration in and of itself does not create binding legal obligations on a State. However, "soft law cannot be simply dismissed as non-law." 83 Rather, “a 'declaration' is a solemn instrument resorted to only in very rare cases relating to matters of major and lasting importance where maximum compliance is expected." ${ }^{24}$ This UN position on declarations was articulated as early as 1962 in a memorandum from the Office of Legal Affairs:

In the United Nations practice, a 'Declaration' is a formal and solemn instrument, suitable to rare occasions when principles of great and lasting importance are being enunciated, such as the Declaration on Human Rights. ... A 'Declaration' is adopted by resolution of a United Nations organ. As such it cannot be made binding upon Member States, in the sense that a treaty or convention is binding upon the parties to it, purely by the device of the terming it a 'Declaration'... However, in view of the greater solemnity and significance of a 'Declaration', it may be considered to impart, on behalf of the organ adopting it, a strong expectation that Member of the international community will abide by it. Consequently, in so far as the expectation is gradually justified by State practice, a Declaration may by custom become recognized as laying down rule binding upon States. ${ }^{85}$

At a minimum, declarations are "an element of good faith commitment, evidencing in some cases a desire to influence state practice or expressing some measure of law-making intention and progressive development.” ${ }^{\prime 6}$ Thus as a resolution of the General Assembly, States are expected to comply with the rights contained in the UN Declaration. ${ }^{87}$ This expectation of compliance is heightened as the UN Declaration was passed by the vast majority of the UN General Assembly and now has received almost unanimous support. $^{88}$

Professor S. James Anaya and Siegfried Wiessner further argue that the UN Declaration uses the language of rights, which is the language of law and thus increases the legal significance and effect of the UN Declaration. ${ }^{89}$ The language of the first preambular paragraph further demonstrates the mandatory nature of compliance, whereby the General Assembly in its consideration of the $U N$ Declaration is to be "guided by the purposes and principles of the Charter of the United Nations, and good faith in the fulfillment of the obligations assumed by States in accordance with the Charter.",90 Connecting the UN Declaration to the mandatory obligations of the UN Charter "clearly implies that

83 Barelli, supra note 29 at 959.

84 Economic and Social Council, Report of the Commission on Human Rights (E/3616/Rev. 1), para. 105, 18th session, 19 March - 14 April 1962.

85 UN Office of Legal Affairs, “Memorandum on Declaration”, UN Doc E/CN.4/L.610, 2 (April 1962).

86 Alan Boyle, "Soft Law in International Law-Making” in Malcolm Evans, ed, International Law (London: Oxford University Press, 2006) 141 at 143.

87 Office of Legal Affairs, supra note 85.

88 Wiessner, supra note 28 at 253.

89 S James Anaya \& Siegfried Wiessner, "The UN Declaration on the Rights of Indigenous Peoples: Towards Reempowerment”, Jurist (3 October 2007) online: Jurist < http://jurist.law.pitt.edu/for-umy/2007/10/un-declaration-onrights-of-indigenous.php>.

90 UN Declaration, supra note 1 at preambular para 1. 
respect of the [Declaration] represents an essential prerequisite in order for States to comply with some of the obligations provided for by the UN Charter." ${ }^{\prime 1}$

While the technical legal status of the UN Declaration is non-binding, Luis Rodriguez-Pinero Royo argues that "if the focus is shifted from the current debate on the formal legal standing of the Declaration towards the legal character of the substantive standards included in the text, the picture may change completely." ${ }^{92}$ Looking at the operative paragraphs, it is clear that the UN Declaration did not create new rights for Indigenous peoples; instead, the UN Declaration expanded upon existing human rights law and clarified the application of general human rights protections to Indigenous peoples. ${ }^{93}$ The purpose of the UN Declaration was not to create a special human rights regime for Indigenous peoples, but rather to repair "the ongoing consequences of the historical denial of the right to self-determination and other basic human rights affirmed in international instruments of general applicability." ${ }^{94}$ In this way, the UN Declaration provides "coherence to a regime previously characterized by different approaches and frameworks." ${ }^{95}$

Canada's additional contention that the Declaration is not representative of customary international law is also contested. The Rights of Indigenous Peoples Committee of the International Law Association, an association of leading academic international law experts on the subject, undertook a review in 2010 to assess whether various aspects of the UN Declaration has attained the status of customary international law. ${ }^{96}$ After their review of existing international law, the Committee concluded that expressed State support for the Declaration, as well as the practice of both States and international bodies "the multiplication of international practice in the field shows the existence not only of the element of State practice, but also of a clear opinio juris, contextually satisfying both elements traditionally needed to prove the existence of a rule of customary international law." ${ }^{97}$ Anaya and Wiessner have argued that one such area where the rights articulated in the UN Declaration have crystallized into customary international law would be the rights to "demarcation, ownership, development, control and the use of lands they have traditionally owned or otherwise occupied and used." 98 The Committee concluded that

even though it cannot be maintained that as a whole [the Declaration] can be considered as an expression of customary international law, some of its key provisions can reasonably be regarded as corresponding to established principles of general international

91 International Law Association, Rights of Indigenous Peoples Committee, “Final Report”, Sofia Conference (2012), online: International Law Association <http://www.ilahq.org/down-load.cfm/docid/227B560E-F0F5-4773BECC974CFC6A11B8> .[Sofia Conference] Luis Rodriguez-Pinero Royo, “'Where Appropriate’: Monitoring/Implementing of Indigenous Peoples’ Rights Under the Declaration" in Charter and Stavenhagen, supra note 4, 314 at 318.

93 S James Anaya, Human Rights Council, "Report of the Special Rapporteur on the Human Rights and Fundamental Freedoms of Indigenous Peoples”, A/HRC/9/9, (August 11, 2008) at para 41. [“Fundamental Freedoms”]

$94 \quad$ Ibid at para 36.

95 Barelli, supra note 29 at 959.

96 Sofia Conference, supra note 91. The Committee looked at the rights of self-determination, cultural rights, land rights, education and media, social and economic improvements, treaty rights, development and international co-operations and finally the provisions on reparations, redress and remedies.

$97 \quad$ Ibid at 28.

98 Anaya \& Wiessner, supra note 89. 
law, therefore implying the existence of equivalent and parallel international obligations to which States are bound to comply with. ${ }^{99}$

This in-depth study of customary international law conducted by internationally renowned international law experts undermines Canada's simple assertion that the UN Declaration does not reflect customary international law. Where the rights in the $U N$ Declaration reflect existing customary international law, those would generally be binding on Canada. ${ }^{100}$ The application of international law in Canada will be discussed in greater detail below.

In addition to academic literature stressing the significance of the UN Declaration and the need to take action to implement it, many domestic and international bodies have begun to cite the $U N$ Declaration when making determinations of Indigenous peoples' rights. ${ }^{101}$ As international and national bodies continue to use it, the UN Declaration "will be able to change indigenous national situations irrespective of its specific international status." 102 Even if all of the rights contained within the UN Declaration have not crystallized into customary international law, as these norms continue to evolve, additional areas of the UN Declaration may reflect customary international law in the future.

Not only does the UN Declaration have legal effect in Canada, even if it is not binding in and of itself, but its extraordinary legitimacy provides strong moral authority to the standards contained and increases the need to implement it. ${ }^{103}$ Legitimacy of an instrument can be ascertained by considering "the different contexts within which an instrument is adopted, the circumstances which have led to its establishment, its very normative content and the institutional setting within which it exists." ${ }^{104}$ The greater the legitimacy, the stronger the moral imperative to uphold the standards contained therein.

In her research, Claire Charters demonstrates the legitimacy of the UN Declaration through the consideration of three factors: "the quality of the processes from which it has sprung, the justice inherent in its content, and the extent to which international actors, be they individuals, civil society, trans-national corporations, states, indigenous peoples and so on, engage with it."105 Charters also concludes that the UN Declaration is extraordinarily legitimate because

it is a result of procedurally legitimate processes; its content is substantively fair and improves the coherence and determinancy of indigenous peoples' rights' and, finally, there has been substantial engagement with the Declaration. In particular, the 25-year plus negotiations that led to the Declaration, conducted in formal, transparent, established and institutionalised settings lend the Declaration enormous legitimacy, as does the openness of those processes. Indigenous peoples could participate at almost every stage. Substantively, the Declaration functions to address some of the historic bias

99 Sofia Conference, supra note 91 at 43.

100 R. v Hape, [2007] 2 SCR. 292 at paras 35-39. [Hape]

101 See e.g. the decision of the Inter-American Court of Human Rights in Case of the Mayagna (Sumo) Awas Tingni Community v Nicaragua, (31 August 2001) Inter-Am CT HR (Ser C) No. 79. [Mayagna]

102 Xanthaki, supra note 6 , at 37.

103 Wiessner, supra note 28 at 259.

104 Barelli, supra note 29 at 960.

105 Claire Charters, "The Legitimacy of the UN Declaration on the Rights of Indigenous Peoples," in Charters and Stavenhagen, Making the Declaration Work, supra note 4 at 280. 
against indigenous peoples under international law by recognising, in particular, indigenous peoples' rights to self-determination and lands, territories and resources. The unique needs of indigenous peoples are now provided for under international law. The Declaration also provides some greater coherence and determinacy to indigenous peoples' rights. It brings most of these rights together into one instrument outlining and clarifying the content of those rights, such as what is meant by the right to selfdetermination in the indigenous context. Finally, the Declaration's legitimacy is set to increase as the world, including states, non-state actors, municipal governments, transnational corporations, individuals and so on, engages with it. Knowledge of the Declaration is high, and, by framing claims in Declaration terms and bringing these to international and domestic political and legal fora, indigenous peoples can propel and increase the pace of states' internalisation of those norms. ${ }^{106}$

Stephen Allen also argues that the rights contained within the UN Declaration "have been infused with considerable political legitimacy derived from the extent to which they have been sanctioned by the international community and as a result of the processes by which the Declaration was developed.”107 The legitimacy of the UN Declaration is increased because it "is the result of ideological debates, diplomatic negotiations, geopolitics, various group interests and personal relations.”"108 Given the high level of legitimacy of the UN Declaration, it "has the normative capacity to influence and guide political discourse while leaving the ultimate political decisions to the national communities concerned.”109

This section has explained that the $U N$ Declaration as a resolution of the General Assembly is not legally binding in and of itself, but it does have strong legal and moral effect in Canada. To the extent that the substantive provisions reflect existing binding international obligations, those provisions of the UN Declaration are binding. As the UN Declaration articulates standards which has legal effect and of which Canada is expected to comply, there may be a need to modify Canadian law so as to ensure conformity with these standards. It is disingenuous for Canada to claim that it will only endorse the $U N$ Declaration to the extent that Canadian law already conforms. While the Constitution is the highest law in Canada, including s. 35(1) recognition and affirmation of Aboriginal and treaty rights, the UN Declaration is instructive of how to interpret this constitutional provision. Further discussions of the application of international in Canada will be set out below.

\section{B. Application of International Law in Canada}

Canadian courts have not always specified how international laws and principles apply domestically when using international law to resolve domestic disputes. ${ }^{110}$ As Canadian courts' embrace of

106 Ibid at 298.

107 Allen, supra note 5 at 250.

108 Stavenhagen, Making the Declaration Work, supra note 4 at 354.

109 Allen, supra note 5 at 250.

110 Hugh M Kindred, Philip M Saunders \& Jutta Brunnée, International Law, Chiefly as Interpreted and Applied in Canada, 7th ed (Toronto: Emond Montgomery, 2006), citing Reference re Secession of Quebec, [1998] 2 SCR 217, 161 DLR (4 $\left.{ }^{\text {th }}\right)$ 385 as one example. 
international law has at times been hesitant, ${ }^{111}$ this article provides two possible ways in which the $U N$ Declaration applies in Canada based on the above understanding of the status of the UN Declaration as a legal instrument. The first approach is based on a normative understanding of the UN Declaration that the substantive rights contained therein reflect other customary international law or other binding human rights treaties. The second approach is based on the presumption of conformity that encourages the interpretation of Canadian law to uphold international human rights law and values.

\section{Customary International Law and International Human Rights Treaties}

\section{(a) Application of Customary International Law in Canada}

The direct application of international law in Canada depends on whether such law is contained within a treaty or customary international law. Canadian courts have generally employed an adoptionist approach to customary international law, provided there is no express conflict in Canadian law. ${ }^{112}$ Justice Lebel recently confirmed this position in $R v$ Hape. ${ }^{113}$ Justice Lebel's initial strong statement that customary international law automatically applies within Canadian law was somewhat qualified by making the application permissive not mandatory: "absent an express derogation, the courts may look to prohibitive rules of customary international law to aid in the interpretation of Canadian law and the development of the common law."114 While some decisions question or limit the adoptionsist approach, ${ }^{115}$ the majority of Canadian decisions have held customary international law directly applies in Canada, ${ }^{116}$ unless there is express legislation to the contrary. Gibran van Ert, a leading Canadian international law scholar has also claimed that after Hape, "the better view is that Canadian law continues to incorporate rules of customary international law." 117

The adoptionist approach means that no specific legislation is required for customary international law to be part of domestic Canadian law. Therefore, where the rights contained within the UN Declaration express rules of customary international law, these protections would be binding on Canada. Thus Canadian law must conform to these obligations, regardless of Canada's position on the UN Declaration. ${ }^{118}$

111 Jutta Brunnée \& Stephen J Toope, “A Hesitant Embrace: The Application of International Law by Canadian Courts” (2002) 40 Canadian YB of Int'l Law 3 at 4.

112 The Ship “North” $v$ R, (1906), 37 SCR 385, 26 CLT 380 at 394.

113 Hape, supra note 100 at para 39.

114 Ibid.

115 See Congo v Venn, [1971] SCR 997; see also Reference Re Mining and Other Natural Resources of the Continental Shelf, (1983), 41 Nfld \& PEIR 271 (Nfld CA).

116 For a recent discussion see Bouzari v Iran, (2004) 71 OR (3d) 675 at para 65, 243 DLR (4th) 406. The Ontario Court of Appeal held that "customary rules of international law are directly incorporated into Canadian domestic law unless explicitly ousted by contrary legislation. So far as possible, domestic legislation should be interpreted consistently with those obligations.” See also Saint John (City) v Fraser-Brace Overseas Corp, [1958] SCR 263; Schreiber v Canada, (2002) SCC 62, [2002] 3 SCR 269; Mack v Canada (AG), [2002] OJ No. 3488 (ONCA); and Kindler v Canada (Minister of Justice), 1991 SCC 70, [1991] 2 SCR 779.

117 Gibran van Ert, Using International Law in Canadian Courts, 2d ed (Toronto: Irwin Law, 2008) at 208. See also Armand de Mestral \& Evan Fox-Decent, "Rethinking the Relationship Between International and Domestic Law" (2008) 53 McGill LJ 573 at 576-7. See also Brunnée \& Toope, supra note 111.

118 UN Declaration, supra note 1. One exception would be if a country is a persistent objector, which is discussed below. 
As stated in the previous section, the recent academic study by the International Law Association's Committee on the Rights of Indigenous peoples ${ }^{119}$ concluded that several sections of the UN Declaration do reflect existing rules of customary international law. ${ }^{120}$ In particular, the study concludes the following rights within the UN Declaration correspond to customary international law:

indigenous peoples have the right to self-determination, that secures to indigenous peoples have the right to decide, within the territory of the State in which they live, what their future will be... indigenous peoples have the right to autonomy or self-government. ... indigenous peoples have the right to recognition and preservation of their cultural identity. ... indigenous peoples have the right to their traditional lands and natural resources. ... indigenous peoples have the rights to reparation and redress for the wrongs suffered. ... indigenous peoples have the right to expect that all treaties, and other agreements to which they are a direct party with a State, that were fairly negotiated, shall be honoured and fully implemented in a manner respecting the spirit and intent of the understanding of the Indigenous negotiators as well as the living nature of the solemn undertakings made by all parties. ${ }^{121}$

A State may not be bound by customary international law if it is a persistent objector. ${ }^{122}$ Canada's practice vis a vis the rights of Indigenous peoples demonstrates that Canada recognizes and accepts a core set of Indigenous peoples' rights. While Canada may contest the precise scope of certain rights, Canada's acceptance of these norms can be seen through the recent endorsement of the UN Declaration. ${ }^{123}$ Canada has actively participated in all international forums relating to Indigenous peoples and their rights, including negotiating the UN Declaration. Canada also continues to report its progress on upholding and promoting Indigenous peoples' rights when they submit periodic reports before human rights bodies. ${ }^{124}$ Given Canada's active involvement in this area, Canada cannot be said to have persistently objected to the protection of rights for Indigenous peoples in international law. With Canada's recent endorsement of the UN Declaration, ${ }^{125}$ there is a strong argument that the rights contained in the UN Declaration that reflect customary international law should be incorporated into Canadian law.

119 The International Law Association is an organization of "academics and practising professionals with an interest in international law. The main objectives of the Association are the study, clarification and development of both public and private international law. It is in the work of the various International Committees that these aims are pursued and biennial conferences provide a forum for comprehensive discussion and endorsement for the work of these committees." Online: International Law Association <http://www.ila-hq.org/>.

120 Sofia Conference, supra note 91 at 29.

121 Ibid at 29.

122 Asylum Case (Colombia v Peru), [1950] ICJ Rep 266 at 277-78.

123 Canada’s Endorsement, supra note 11.

124 Canada's fifth periodic report submitted to the Human Rights Committee, Doc CCPR/C/CAN/2004/5. See also See Final Report of the Seventieth Session of the CERD, Doc A/62.18.

125 Canada's Endorsement, supra note 11. 


\section{(b) Application of International Treaties in Canada}

Under international law, an international treaty is binding on Canada if it has signed and ratified the treaty and the treaty has entered into force. ${ }^{126}$ In Canada, it is generally accepted that treaties must be transformed into domestic law before they apply, usually by passing legislation that specifically implements a treaty. ${ }^{127}$ One example is the Crimes Against Humanity and War Crimes Act, ${ }^{128}$ which implemented the Rome Statute of the International Criminal Court. ${ }^{129}$ However, not all legislation implementing an international treaty is quite so obvious. ${ }^{130}$

Canada has ratified other general human rights treaties, which protect Indigenous peoples' rights, such as the International Covenant on Civil and Political Rights ${ }^{131}$ and the International Convention on the Elimination of All Forms of Racial Discrimination. ${ }^{132}$ Canada has not taken steps to transform ratified international human rights treaties, but rather claims "most human rights treaties are ratified by Canada on the basis that existing domestic laws and programs already conform with a treaty's obligations and no new legislation is required." 133 Accepting Canada's statement that further action is not needed to transform these human rights treaties into domestic law, leads to the conclusion that these treaties are part of Canadian law. But even an unimplemented treaty may still have some legal effect within Canadian law. ${ }^{134}$

As argued above, the substantive rights contained within the $U N$ Declaration relate to provisions found in general human rights treaties and other Indigenous specific instruments such as the International Labour Organization Convention No $169 .{ }^{135}$ In this way, the UN Declaration provides a frame of reference to interpret existing human rights obligations in relation to Indigenous peoples. ${ }^{136}$ The $U N$ Declaration is arguably applicable in Canada as it "elaborates upon these fundamental rights in the specific cultural, historical, social and economic circumstances of indigenous peoples”"137 articulated in various human rights treaties Canada has ratified, such as the International Convention on the Elimination of All Forms of Racial Discrimination; ${ }^{138}$ International Covenant on Civil and Political Rights; ${ }^{139}$ International Covenant on Economic, Social and Cultural Rights; ${ }^{140}$ Convention on the Elimination of Discrimination Against Women; ${ }^{141}$ and the Convention on the Rights of the Child. ${ }^{142}$

\footnotetext{
126 Mark Freeman \& Gibran van Ert, International Human Rights Law (Toronto: Irwin Law, 2004) at 57-8. See Francis v R, [1956] SCR 618 at 621. See also Capital Cities Communications Inc v Canadian Radio-Television Commission, [1978] 2 SCR 141 at 173. See also, Baker v Canada [1999] 2 SCR 817 at 861. [Baker]

128 Crimes Against Humanity and War Crimes Act, SCC 2000, c. 24.

129 UN Doc A/CONF 183/9; 37 ILM 1002 (1998); 2187 UNTS 90. Canada ratified this treaty on July 7, 2000.

130 Freeman \& van Ert, supra note 126 at 166-7.

131 International Covenant on Civil and Political Rights, GA Res 2200A (XXI) CCPR (1996). [ICCPR]

132 International Convention on the Elimination of all forms of Racial Discrimination, GA Res 2106 (XX) CERD (1965). [ICERD]

133 Irit Weiser, "Effect of International Human Rights Treaties Ratified Without Implementing Legislation” in The Impact of International Law in the Practice of Law in Canada, Canadian Council on International Law (The Hague: Kluwer Law, 1998) 132 at 132.

134 See Baker, supra note 127 at para 69.

135 Royo, supra note 92.

136 Ibid at 314 and 319. This position can be contrasted with the work of Stephen Allen; Allen, supra note 5.

137 Anaya, "Fundamental Freedoms", supra note 93 at para 40.

138 ICERD, supra note 132.

139 ICCPR, supra note 131.
} 


\section{Presumption of Conformity}

A second approach for the domestic application of the UN Declaration is using the presumption of conformity whereby the UN Declaration can be used to interpret Canadian law including s. 35(1) of the Constitution Act, 1982. Providing interpretations of domestic law supported by international declarations is not a new practice, in fact "international declarations have been cited by the judiciary on countless occasions."143

The presumption of conformity requires that Canadian law be interpreted consistent with Canada's international obligations. ${ }^{144}$ The presumption of conformity allows courts to use international principles as an interpretive tool for domestic law - statutory, constitutional or judicial review. These obligations include international conventions not yet transformed into Canadian law ${ }^{145}$ and also other non-binding obligations. ${ }^{146}$ The presumption of conformity has also been used in relation to Charter litigation, ${ }^{147}$ and as s. 35(1) is also encompassed within the Constitution Act, 1982, it is reasonable to use the presumption of conformity.

In Ordon Estate v Grail, Justices Iacobucci and Major used the presumption of conformity when interpreting a domestic statute, holding that "although international law is not binding upon Parliament or the provincial legislatures, a court must presume that legislation is intended to comply with Canada's obligations under international instruments and as a member of the international community." ${ }^{148}$ In reaching this position, Justices Iacobucci and Major cited Driedger on the Construction of Statutes. ${ }^{149}$ A second example where the Supreme Court of Canada has used the presumption of conformity is in Baker, where Justice L'Heureux Dubé writing for the majority of the Court determined the Convention on the Rights of the Child, which had not been transformed into Canadian law, was relevant to the appeal at hand. She held that "the values reflected in international human rights law may help inform the contextual approach to statutory interpretation and judicial review."150

Where an ambiguity exists or clarification is needed in domestic law (for example, on the scope of s. 35(1)), the presumption of conformity permits international standards such as those articulated within the UN Declaration to be used to interpret Canadian law. This approach develops Canadian law in a way that upholds Canada's international obligations. Drawing upon the principle of conformity, Karen Knop argues that Baker is indicative of the court's shift from a focus on the dichotomy of bindingness/non-bindingness to a focus of persuasiveness of the international principle for the

140 International Covenant on Economic, Social and Cultural Rights, 16 December 1966, UNTS 993 at 3. [ICESCR]

141 Convention on the Elimination of All Forms of Discrimination Against Women, 18 December 1979, UNTS 1249 at 13.

142 Convention on the Rights of the Child, 20 November 1989, UNTS, 1577 at 3.

143 Joffe, supra note 58 at 201.

144 Canadian Foundation for Children, Youth and the Law v Canada (AG), 2004 SCC 4, [2004] 1 SCR 76, 234 DLR (4 $\left.{ }^{\text {th }}\right)$ 257 at para 31, citing Ordon Estate v. Grail, [1998] 3 SCR 437 at para 137.

145 Baker, supra note 127.

146 See 114957 Canada Ltee (Spraytech, Societe d'arrosage) v Hudson (Town), [2001] 2 SCR 241 at para 30 where Justice L'Heureux Dube held that the municipal by-law regulating the use of lawn chemicals was consistent with principles of international law and policy.

147 Canadian Foundation for Children, Youth and the Law v Canada (AG), 2004 SCC 4, [2004] 1 SCR 76, 234 DLR (4 $\left.{ }^{\text {th }}\right)$ 257.

148 Ordon Estate v. Grail, [1998] 3 SCR 437 at 526.

149 Ruth Sullivan, Driedger on the Construction of Statutes (Toronto: Butterworths, 3rd ed. 1994) at 330.

150 Baker, supra note 127. 
determination of Canadian law. ${ }^{151}$ This shift further supports the need for Canadian law to be developed in line with international norms on the rights of Indigenous peoples contained within the $U N$ Declaration because they are highly persuasive given their nearly universal support and have a high degree of legitimacy. ${ }^{152}$

At a minimum, international norms should be used in the purposive and contextual approach to interpreting Aboriginal and treaty rights protected under s. 35(1) of the Constitution Act, $1982 .{ }^{153}$ This approach of using international law to interpret Aboriginal and treaty rights is increasingly gaining favour. Joffe argues that "with respect to the Aboriginal and treaty rights of Indigenous peoples in Canada, reliance upon international concepts is highly appropriate."154 Chief Justice McLachlin, has also supported such an approach when she expressed her opinion that, "Aboriginal rights from the beginning have been shaped by international concepts. . . . Whether we like it or not, aboriginal rights are an international matter." 155

Applying the presumption of conformity in Canada has the additional benefit of aligning with the normative approach to interpreting international human rights used in international human rights bodies. $^{156}$ In particular, both approaches place less focus on the bindingness of any particular instrument; rather the focus is on identifying and applying normative developments in human rights to ensure greater coherence between systems. The normative approach and the presumption of conformity shift the focus away from whether or not Canada is bound by a specific instrument. Rather, these approaches identify emerging norms of Indigenous peoples' rights encapsulated in human rights treaties, declarations, international decisions and writings of experts. We can then use the norms articulated in this vast body of international law, including the most recent and comprehensive articulation found in the UN Declaration, to interpret Canadian law in conformity with those developments.

\section{Other Actions to Overcome Obstacles and Implement the UN Declaration}

The previous section demonstrated that the UN Declaration has legal effect and moral authority in Canada. This section provides specific actions to be taken to implement the UN Declaration in Canada and give meaningful effect to the standards set out therein. The process of implementing the standards set out in the UN Declaration must be multi-faceted. The UN Declaration can be used in many ways in Canada:

151 Karen Knop, “Here and There: International Law in Domestic Courts,” (2000) 32 International Law and Politics 501.

152 See almost unanimous support for the UN Declaration on the Rights of Indigenous Peoples as one recent articulation of these rights.

153 In $R$ v Sparrow, [1990] 1 SCR 1075 at 1106 [Sparrow], Chief Justice Dickson, writing for the Court, held “Section 35(1) is to be construed in a purposive way. A generous, liberal interpretation is demanded given that the provision is to affirm aboriginal rights."

154 Joffe, supra note 58 at 135.

155 Ibid. citing Chief Justice McLachlin's statements at the Order of Canada Luncheon in February 2002.

156 See e.g. Mayagna, supra note 101, in particular the concurring opinion by Judge Sergio García Ramírez in the Judgment on the Merits and Reparations, at paras 6-9. See also Maya Indigenous Communities of Toledo District v Belize, Report No 40/04, Case 12.053 at para 87-8. See also James Anaya \& Claudio Grossman, “The Case of Awas Tingni v.

Nicaragua: A New Step in the International Law of Indigenous Peoples” (2002) 19 Ariz J Int'l \& Comp L 1 at 12. 
it can inform public opinion, influence public policy, and guide future jurisprudence. As Indigenous peoples, we can use it in our pursuit for the full recognition, respect, and implementation of our rights at home. Human rights institutions and courts can use the Declaration as a standard to measure how Canada behaves toward our peoples, our communities, and our nations. ${ }^{157}$

These various approaches will be detailed in this section.

As discussed previously, there are no legal barriers to implementing the UN Declaration in Canada; instead the major problem is a lack of political will. Trying to garner political will is difficult, but "political engagement at a national level" is critical to implement the UN Declaration. ${ }^{158}$ The Canadian government has set out a consistent message that the UN Declaration may not be compatible with Canadian law and may jeopardize non-Indigenous property interests. ${ }^{159}$ These campaigns of misinformation must be publically corrected. Indigenous peoples and their allies have the unfortunate responsibility to ensure that the general Canadian public understands the significance and purpose of the UN Declaration, which has the stated purpose to "enhance harmonious and cooperative relations between the State and indigenous peoples, based on principles of justice, democracy, respect for human rights, non-discrimination and good faith." ${ }^{160}$ Through public engagement and education, the provisions of the UN Declaration can be brought to life in Canada. ${ }^{161}$

Public support for the UN Declaration can be gained through greater public awareness and understanding, which can be created through collaborative efforts with Indigenous peoples and their allies. ${ }^{162}$ This includes educating both Indigenous ${ }^{163}$ and non-Indigenous peoples. ${ }^{164}$ One approach that several organizations have taken is to develop materials on the UN Declaration. ${ }^{165}$ There is also a handbook being developed for Parliamentarians. ${ }^{166}$ The Special Rapporteur on the Rights of Indigenous Peoples recognized the importance of public education: "Until the non-indigenous sectors of the

157 Phil Fontaine, “A Living Instrument,” in Hartley, Joffe \& Preston, supra note 46, 8 at 10.

158 Allen, supra note 5 at 226.

159 Canada's Endorsement, supra note 11.

160 UN Declaration, supra note 1 at preambular para 18.

161 Sambo-Dorough, supra note 50 at 264.

162 Ibid.

163 See e.g. Assembly of First Nations “The United Nations Declaration on the Rights of Indigenous Peoples: What It Says and What It Means for First Nations in Canada” online: Assembly of First Nations

$<$ http://www.afn.ca/index.php/en/policy-areas/implementing-the-united-nations-declaration-on-the-rights-of-indigenouspeo>

164 James Anaya, Human Rights Council "Statement of the Special Rapporteur on the rights of indigenous peoples, Expert Mechanism on the Rights of Indigenous Peoples Fifth Session,” 12 July 2011, online: Indigenous Peoples' Center for Documentation, Research and Information < http://www.docip.org/Online-Documentation.32.0.html> at 2. [Statement of the Special Rapporteur]

165 See e.g. Brenda Gunn "Understanding and Implementing the UN Declaration on the Rights of Indigenous Peoples: An Introductory Handbook” (2011), online: Indigenous Bar Association

<http://www.indigenousbar.ca/pdf/undrip_handbook.pdf>. See also Australian Human Rights Commission, "Community Guide to the UN Declaration on the Rights of Indigenous Peoples” (2010), online: Australian Human Rights Commission <http://www.humanrights.gov.au/sites/default/files/document/publication/declaration_community_guide.pdf>.

166 Littlechild, supra note 44. 
societies within which indigenous peoples live come to share in awareness about the Declaration and its goals, it will remain difficult for those goals to be achieved amid competing political, economic and social forces." 167 Continued academic consideration of the UN Declaration and how it fits within the Canadian legal landscape is a critical component to promoting informed dialogue on the UN Declaration. ${ }^{168}$

Public education alone will not satisfy the rights set out in the UN Declaration. Stephen Allen explains that "in order to secure the kind of municipal legal rights that will protect and promote their societal identities in concrete ways, indigenous peoples need to (re)engage in democratic political processes within their States." 169 Another important way to push for implementation of the UN Declaration is through the legislative and constitutional processes. ${ }^{170}$ Given that Canada already recognizes Indigenous peoples' rights in the Constitution, the next step may be to have implementing legislation that clarifies the scope of these rights. In undertaking such a process, the UN Declaration is instructive for both procedural and substantive issues as it "offers a route to building genuine national consensus on indigenous issues." 171

Full implementation of the UN Declaration in Canada will require governments to review existing laws and policies to ensure compliance with the standards set out in the UN Declaration. ${ }^{172}$ Indigenous peoples can play an important role lobbying for such a review and also identifying specific pieces of legislation and policy that do not conform with the international standards of the UN Declaration. Article 19 of the UN Declaration requires governments to "consult and cooperate in good faith with the indigenous peoples concerned through their own representative institutions in order to obtain their free, prior and informed consent before adopting and implementing legislative or administrative measures that may affect” Indigenous peoples.

However, it is not sufficient merely to ensure laws reflect the standards set out in the UN Declaration because "even where there is adequate protection of indigenous peoples' rights and there are wellestablished laws to combat discrimination, appropriate administrative measures may not be in place to ensure their application in practice." 173 Effective realization of Indigenous peoples rights requires that "States, in conjunction with Indigenous peoples, establish national plans of work to implement the Declaration with clear timelines and priorities. States should report regularly on the progress and shortcomings in implementing the UN Declaration to their national legislatures and to EMRIP."174 National plans should include necessary administrative measures and regulations to give effect to the laws. These plans must acknowledge and address ongoing institutional discrimination where Indigenous

\footnotetext{
167 Anaya, Statement of the Special Rapporteur, supra note 164.

168 See e.g., James (Sa’ke'j) Youngblood Henderson, Indigenous Diplomacy and the Rights of Peoples: Achieving UN Recognition (Saskatoon: Purich Publishing, 2008), ch 9 at 90.

169 Allen, supra note 5 at 252.

170 Burger, supra note 71at 56.

171 Allen, supra note 5 at 254.

172 This was called for in a private members bill presented by Tina Keeper, MP and Wilton Littlechild, MP.

173 Burger, supra note 71, 41 at 57.

174 Joint Statement of Indigenous World Association, et al. to Expert Mechanism on the Rights of Indigenous Peoples, Fourth session, Geneva, 11-15 July 2011, Agenda Item 5: Implementation of the UN Declaration on the Rights of Indigenous Peoples. Available through DoCip: http://www.docip.org/Online-Documentation.32.0.html.
} 
peoples issues have generally been ignored, including "objectives, priorities, budgets, administration, capacity building, evaluation, feedback, [and] coordination." 175

When setting priorities, "the importance of adequate quantitative information and reliable indicators cannot be overstated because they are necessary to formulate the right public policies and target the neediest populations." ${ }^{176}$ In Canada, we will need to have aggregated statistics on socio-economic conditions of Indigenous peoples, including women, to ensure that policy and administrative measures are appropriately targeted to address those issues.

There are other steps that should be taken to implement the UN Declaration, including the formal endorsement by Indigenous governments. ${ }^{177}$ The Assembly of First Nations ${ }^{178}$ and the Grand Council of Mi'kmaw Nation ${ }^{179}$ have already taken this step. Endorsing the UN Declaration is an exercise of selfdetermination and self-governance. The Grand Council of the Mi'kmaw Nation's endorsement recognizes the $U N$ Declaration as an interpretive and implementation guide to Mi'kmaw selfdetermination, collective rights and responsibilities. ${ }^{180}$

A second way that Indigenous communities can implement the UN Declaration is to ensure that their own laws and policies meet the standards set out in the UN Declaration. The Mi'kmaw Nation's endorsement also strives to "promote respect for, and progressive implementation of the rights and freedoms of indigenous peoples as set out in the United Nations Declaration on the Rights of Indigenous Peoples, within our own territory, within our region and abroad."181

Another critical step to implementing the $U N$ Declaration is by citing it in domestic courts. This approach of using the UN Declaration to interpret domestic law has been promoted by the UN Special Rapporteur on Indigenous Rights, S. James Anaya: "even if not empowered to directly apply the Declaration, domestic courts may and should use the Declaration as an interpretive guide in applying provisions of domestic law." ${ }^{182}$ The Special Rapporteur cites a recent decision of the Supreme Court of Belize where the court interpreted the Belizean constitution in light of the UN Declaration and other international sources to uphold the Mayan peoples land rights. ${ }^{183}$ Julian Burger further notes that courts will play a critical role in implementing the UN Declaration, however it is important that these courts are well informed. ${ }^{184}$

Given the potential limited exposure judges may have to international law, lawyers may need to provide background on international law's application in Canada and the relevance of the UN Declaration when citing the UN Declaration in pleadings and in court. As explained in the previous

175 Stavenhagen, Making the Declaration Work, supra note 4 at 362.

176 Ibid at 361.

177 Sambo-Dorough, supra note 50 at 273.

178 Assembly of First Nations, “Resolution No. 37”, Special Chiefs Assembly 11-13 December 2007, Ottawa, online: AFN $<$ http://64.26.129.156/article.asp?id=4064>.

179 Letter from Grand Council of Mi’kmaw Nation to the United Nations High Commissioner for Human Rights and Chairperson of the United Nations Permanent Forum on Indigenous Issues (27 July 2008). [unpublished]

180 Ibid.

181 Ibid.

182 Anaya, "Fundamental Freedoms”, supra note 93 at para 54.

183 Manuel Coy et al. v The Attorney General of Belize et al., Supreme Court of Belize, Claims No. 171 and 172 (19 October 2007).

184 Burger, supra note 71 at 57. 
section, the UN Declaration can be used an interpretive tool for the rights protected under s. 35(1) of the Constitution Act, 1982 as well as other Canadian laws and policies relating to Indigenous peoples. ${ }^{185}$ In relation to the Charter, former Chief Justice Dickson held that "the various sources of international human rights law - declarations, covenants, conventions, judicial and quasi-judicial decisions of international tribunals, customary norms - must, in my opinion, be relevant and persuasive sources for interpretation of the Charter's provisions."186 If declarations can be used to interpret the Charter, then the argument is strong that the UN Declaration can be used to interpret s. 35(1). Recently, in the Roger William $v$ British Columbia appeal before the Supreme Court of Canada, interveners Amnesty International and Canadian Friends Service Committee argued that the Court should use the UN Declaration to interpret Aboriginal title under s. 35(1). ${ }^{187}$

If lawyers and advocates do not cite the UN Declaration in their pleadings and arguments, the courts will not be able to consider the $U N$ Declaration in their decisions. It is important to encourage the courts to take a flexible and generous approach to interpreting the UN Declaration, as is generally done in Canadian constitutional interpretation. ${ }^{188}$ By citing the UN Declaration in domestic pleadings, the Canadian courts have an opportunity to consider UN Declaration it's application in the domestic context. This can have significant impact on the weight of the UN Declaration domestically.

Outside of the courts, another method to promote the implementation of the UN Declaration is to refer to the standards when negotiating with Canadian governments (both federal and provincial). Dalee Sambo Dorough advocates for the use of the UN Declaration in negotiations, citing the example of Alaskan Native tribal governments use "to redefine political and legal relationships between local governments and indigenous governments.” 189 When engaging in self-government negotiations, many articles in the UN Declaration provide some useful guidance on the scope of possible self-government arrangements.

As discussed above, the UN Declaration includes the right to self-determination (article 3), and it also states "Indigenous peoples have the right to maintain and strengthen their distinct political, legal, economic, social and cultural institutions, while retaining their right to participate fully, if they so choose, in the political, economic, social and cultural life of the State."190 Article 18 is important in self-government negotiations because it sets out that "Indigenous peoples have the right to participate in decision-making in matters which would affect their rights, through representatives chosen by themselves in accordance with their own procedures, as well as to maintain and develop their own indigenous decision-making institutions." This article is supported by the provision in article 20 that Indigenous peoples have the right "to maintain and develop their political, economic and social systems or institutions.” Several articles make reference to the protection and promotion of Indigenous

\footnotetext{
185 Constitution Act, supra note 15.

186 Reference re Public Service Employee Relations Act (Alberta), [1987] 1 S.C.R. 313 at para 57.

187 Factum for Intervener Amnesty International and Canadian Friends Service Committee, Roger William v British Columbia. Court File No. 34986. Oral arguments heard November 7, 2013.

188 See Edwards v Canada (Attorney General) (1929), [1930] AC 124, 1929 CarswellNat 2 (Canada P.C.), at 136: “The [Constitution Act, 1867] planted in Canada a living tree capable of growth and expansion within its natural limits.” See also Sparrow, supra note 153, Dickson C.J.C. holds: “A generous, liberal interpretation is demanded given that the provision is to affirm aboriginal rights."

189 Sambo-Dorough, supra note 50 at 273.

190 UN Declaration, supra note 1 at Article 5.
} 
traditions, laws and customs in relation to belonging to Indigenous communities or nations and the right to practice, preserve and transmit these traditions; ${ }^{191}$ which may be better achieved through selfgovernment arrangements. Some of the areas that are set out in the UN Declaration which may be prime for self-government include the establishment and control education systems and institutions; ${ }^{192}$ the administration of health, housing and other economic and social programmes; ${ }^{193}$ and determination of membership. ${ }^{194}$

Similarly, the UN Declaration includes provisions that could set minimum standards for land claim negotiations. The UN Declaration requires States to give legal recognition and protection to Indigenous peoples' "lands, territories and resources which they have traditionally owned, occupied or otherwise used or acquired." 195 It further stipulates that there is to be "a fair, independent, impartial, open and transparent process" to adjudicate Indigenous peoples' land rights. ${ }^{196}$ The adjudication process is to give "due recognition to indigenous peoples' laws, traditions, customs and land tenure systems." 197 The UN Declaration includes a right to redress for lands for lands "which have been confiscated, taken, occupied, used or damaged without their free, prior and informed consent." ${ }^{198}$ Free, prior and informed consent is the general standard by which government conduct is measured in relation to Indigenous peoples' land. The UN Declaration also sets out the right to set development strategies on their lands and requires governments to obtain Indigenous peoples' free prior and informed consent before approving projects that affect Indigenous peoples’ lands. ${ }^{199}$

As indicated in this section, there are a many different avenues to implement the UN Declaration: education, law reform, litigation, and negotiation. It is through the pursuit of all these methods that the standards contained within the UN Declaration will begin to provide tangible benefits to Indigenous peoples.

\section{CONCLUSION}

The UN Declaration is a key instrument for the promotion and protection of Indigenous peoples' rights. It represents a culmination of many years of advocacy, so that today "Indigenous rights have never been given as much attention at the international level as they are presenting receiving."200 While the UN Declaration final text includes several compromises and challenges exist to its implementation process, these reasons are not sufficient to justify inaction on the UN Declaration.

While the UN Declaration is not legally binding, it still has legal effect in Canada. As a declaration, there is a strong expectation that Canada will work to uphold the rights and domestically implement the standards contained within it. The rights in the UN Declaration "are not automatically effective... They

\footnotetext{
191 Ibid at Articles 9, 11, 12, 13 and 34.

192 Ibid at Article 14.

193 Ibid at Article 23.

194 Ibid at Article 33.

195 Ibid at Article 26.

196 Ibid at Article 27.

197 Ibid at Article 27.

198 Ibid at Article 28.

199 Ibid at Article 32.

200 Xanthaki, supra note 6 at 34.
} 
must be interpreted, balanced and/or shaped before they can be applied." ${ }^{201}$ Bringing the UN Declaration into the national level will allow for the rights to be realized. The UN Declaration recognizes that Indigenous peoples are an essential player in the formulation of the laws and policies affecting their lives. Importantly, the UN Declaration provides a framework for re-building the relationship between Indigenous peoples and Canada based on partnership and mutual respect.

In Canada, the UN Declaration can be used to provide greater understanding of the scope of the existing affirmation and recognition of Aboriginal and treaty rights within the Canadian constitution. While greater education of all sectors of Canadian society is necessary to increase political will for full implementation, there are many steps Indigenous peoples can take to begin implementing the $U N$ Declaration at a local level.

201 Allen, supra note 5 at 255. 